\title{
ANALISA KEKUATAN BENDING FILAMEN ABS DAN PLA PADA HASIL 3D PRINTER DENGAN VARIASI SUHU NOZZLE
}

\author{
Laily Noor Ikhsanto ${ }^{1}$, \\ Jurusan Teknik Mesin, Program Studi DII Teknik Mesin \\ PDD Politeknik Negeri Bandung \\ E-mail: lailynoorikhsanto@gmail.com \\ Zainuddin ${ }^{2}$ \\ Jurusan Teknik Mesin, Program Studi DII Teknik Mesin \\ PDD Politeknik Negeri Bandung \\ E-mail: zainuddin060590@gmail.com
}

\begin{abstract}
ABSTRAK
Tujuan pada Penelitian ini adalah untuk Mengetahui kekuatan dan pengaruh suhu dari jenis Filamen ABS dan PLA Hasil Proses 3D-Printer terhadap Kekuatan Bending. Spesimen yang digunakan dalam penelitian ini menggunakan 2 macam Filamen, yaitu: PLA dan ABS. Dalam proses pembuatan nya menggunakan suhu nozzle $230^{\circ} \mathrm{C}, 237^{\circ} \mathrm{C}$ dan $244^{\circ} \mathrm{C}$. Selanjutnya proses pembuatan spesimen diawali dengan membuat gambar spesimen yang akan dibuat menggunakan software Catia. Ukuran spesimen yang digambar sesuai dengan standart ASTM D955. Hasil dari penelitian ini didapatkan Filamen ABS dengan suhu $230^{\circ} \mathrm{C}$ dapat menahan beban sebesar 26.863 $\mathrm{N}$, Filamen ABS dengan suhu $237^{\circ} \mathrm{C}$ dapat menahan beban sebesar $27.141 \mathrm{~N}$, dan Filamen ABS dengan suhu $244^{\circ} \mathrm{C}$ dapat menahan beban sebesar $28.236 \mathrm{~N}$. sedangkan Filamen PLA dengan suhu $230^{\circ} \mathrm{C}$ dapat menahan beban sebesar $22.38 \mathrm{~N}$, Filamen PLA dengan suhu $237^{\circ} \mathrm{C}$ dapat menahan beban sebesar $23.71 \mathrm{~N}$, dan Filamen PLA dengan suhu $244^{\circ} \mathrm{C}$ dapat menahan beban sebesar 28.06 $\mathrm{N}$. Berdasar hasil pengukuran menggunakan Uji Bending menunjukkan bahwa, hasil 3D printing dengan suhu nozzle semakin tinggi maka beban yang dapat ditahan semakin besar. Hal ini berlaku sebaliknya, yaitu hasil 3D printing dengan suhu nozzle semakin rendah maka beban yang dapat ditahan semakin kecil pula. Filamen ABS lebih kuat menahan beban daripada Filamen jenis PLA, tetapi Filamen PLA lebih lentur dibandingkan dengan Filamen jenis ABS. ABS lebih kuat daripada PLA karena dari hasil uji bending untuk mencapai displacement $3 \mathrm{~mm}$, Filamen ABS mampu menahan beban yang lebih berat daripada Filamen PLA. PLA lebih lentur daripada ABS didasarkan pada hasil uji bending menunjukkan bahwa untuk mencapai displacement $3 \mathrm{~mm}$, Filamen PLA memerlukan beban yang lebih ringan daripada Filamen ABS.
\end{abstract}

Kata Kunci :3D-Printer, Rapid Prototyping, Filamen, Suhu Nozzle, Bending.

\begin{abstract}
The purpose of this study was to determine the strength and influence of the temperature of the ABS and PLA Filament types from the 3D-Printer Process on Bending Strength. Specimens used in this study used 2 types of filament, namely: PLA and ABS. In the manufacturing process using nozzle temperatures $230^{\circ} \mathrm{C}, 237^{\circ} \mathrm{C}$ and $244^{\circ} \mathrm{C}$. Furthermore, the process of making specimens begins with drawing images of specimens that will be created using Catia software. The size of the specimen drawn is according to the ASTM D955 standard. The results of this study found that ABS
\end{abstract}


Filament with a temperature of $230^{\circ} \mathrm{C}$ can withstand a load of $26,863 \mathrm{~N}$, Filament $\mathrm{ABS}$ with a temperature of $237^{\circ} \mathrm{C}$ can withstand a load of 27,141 N, and ABS Filament with a temperature of $244^{\circ} \mathrm{C}$ can withstand a load of 28,236 N. While Filament PLA with a temperature of $230^{\circ} \mathrm{C}$ can withstand a load of $22.38 \mathrm{~N}$, PLA filaments with a temperature of $237^{\circ} \mathrm{C}$ can withstand a load of $23.71 \mathrm{~N}$, and a PLA Filament with a temperature of $244^{\circ} \mathrm{C}$ can withstand a load of $28.06 \mathrm{~N}$. Based on the results of measurements using the Bending Test shows that $3 D$ printing results with a higher nozzle temperature, the greater the load that can be withstand. This applies vice versa, namely the results of $3 D$ printing with nozzle temperatures lower the load that can be held the smaller. ABS Filaments are stronger in weight than PLA Filaments, but PLA Filaments are more flexible than ABS Filaments. ABS is stronger than PLA because of the bending test results to achieve a displacement of $3 \mathrm{~mm}$, ABS Filament is able to withstand heavier loads than PLA Filament. PLA is more flexible than ABS based on the results of bending tests showing that to achieve a displacement of $3 \mathrm{~mm}$, PLA Filaments require a lighter load than ABS Filaments.

\section{Keywords: 3D-Printer, Rapid Prototyping, Filament, Nozzle Temperature, Bending}

\section{PENDAHULUAN}

Attaran (2017) menjelaskan bahwa Teknologi 3D printing membawa perubahan besar pada dunia. Teknologi yang juga dikenal dengan sebutan Additive Layer Manufacturing ini sebenarnya sudah ada sejak tahun 1980-an. 3D printing merupakan sebuah terobosan baru dalam dunia teknologi. Terobosan ini sangatlah populer di seluruh belahan dunia, terutama di kalangan akademisi dan industri. Munculnya teknologi 3D Printing sangat berpengaruh pada beberapa bidang industri, terutama dari segi ekonomi. Rapid Prototyping pada komponen mekanik dengan teknik-teknik dan volume produksi yang rendah dalam memproduksi prototype dengan cepat.

3D Printing memiliki potensi yang besar dalam dunia manufaktur saat ini. Pembuatan produk secara cepat dari suatu model CAD merupakan tuntutan yang sangat penting mengingat kecenderungan proses pembuatan produk harus dapat dilakukan dengan waktu yang lebih pendek. Pembuatan produk dengan cara Rapid Prototyping tidak memerlukan perencanaan proses seperti pada umumnya untuk membuat suatu produk, tetapi hanya berdasarkan informasi model 3D dari suatu produk saja.

Penelitian yang dilakukan oleh Seprianto, Wilza,\& Iskandar (2017) tentang bagaimana membuat produk yang lebih variatif (high variety) dengan harga murah (low price). Prinsip ini dikenal dengan build to order, produk yang disesuaikan namun dapat diproduksi secara massal pula. Metode yang dapat menjawab tantangan tersebut adalah additive manufacturing menggunakan alat 3D Printing. Pembuatan objek menggunakan 3D Printing memanfaatkan data $\mathrm{CAD}$ yang telah terlebih dahulu dibuat. Penelitian ini bertujuan untuk mendapatkan kombinasi parameter optimal pada proses pembuatan objek 3D Printing sehingga menghasilkan geometri yang akurat sesuai dengan yang direncanakan. Parameter proses yang diinvestigasi adalah layer height, print speed, perimeter shells dan waktu polishing. Spesimen uji dibuat dengan material polysmooth TM mengacu ASTM D995-08 menggunakan 3D Printer type Fused Deposition Modeling (FDM). Data hasil pengukuran dianalisa menggunakan ANOVA dengan design type 2 level factorial dan design model 4 factorial interactions (4FI) berbantukan perangkat lunak Design-Expert ${ }^{\circledR}$ versi trial. Hasil ANOVA diketahui bahwa faktor-faktor secara signifikan $(\alpha=0.05)$ berpengaruh terhadap geometri objek 3D Printing dan kombinasi parameter optimal yaitu layer height $=0.14 \mathrm{~mm}$, print speed $=51.73 \mathrm{~m} / \mathrm{s}$, perimeter shells $=3 \mathrm{~mm}$ dengan waktu polishing $=20$ menit.

Penelitian tentang kekuatan struktur mekanik yang dilakukan oleh Amri dan Sumbodo (2018) tentang perancangan desain rangka 3D Printer tipe Core XY menggunakan software Autodesk Inventor 2015 dan mengetahui kualitas produk hasil 3D Printer yang dibuat. Penelitian ini merupakan jenis perancangan dengan metode Pahl \& Beitz dengan tahapan penjabaran tugas atau 
spesifikasi, perancangan konsep, perancangan wujud, dan perancangan secara terperinci. Analisis data menggunakan statistik deskriptif. Hasil analisis data menunjukkan bahwa kekuatan rangka 3D Printer cukup baik dibuktikan dengan analisis menggunakan software Autodesk inventor 2015 dan hasil benda kerja yang diproses menggunakan 3D Printer mempunyai nilai kepresisian dengan toleransi $\pm 0.5 \mathrm{~mm}$ dibuktikan dengan hasil pengukuran benda kerja dengan menggunakan alat ukur. Jadi disimpulkan bahwa 3D Printer tipe core XY yang dibuat layak digunakan untuk proses pembuatan benda 3 Dimensi.

Penelitian yang dilakukan oleh Pristiansyah dan Herianto (2018) tentang pengukuran tingkat transparansi hasil cetak mesin 3D Printing FDM untuk fillament PETG (Polyethylene Terephthalate Glycol) dengan mengacu pada pengaturan parameter dari software slicing 3D Printing dan mesin yang digunakan, dan tingkat transparansi hasil cetak menggunakan Lux Meter. Metode yang digunakan pada penelitian ini, yaitu metode eksperimental dengan mengacu pada parameter seperti, suhu nozzle, suhu bed, kecepatan cetak, dan tebal tipis material per layer (layer height). Berdasarkan hasil eksperimen dan pengukuran maka akan ditentukanlah parameter yang menghasilkan objek cetak yang memiliki tingkat trasparansi paling baik. Dengan adanya penelitian ini diharapkan para penggiat 3D Printing dapat membantu para dokter untuk bekerja secara optimal dalam menganalisa kerusakan pada organ dalam tubuh manusia.

Penelitian selanjutnya Artahaya dan Fransiscus (2015) mempelajari tentang kemampuan yang dimiliki oleh mesin, terkait dengan pembuatan dinding produk, keraatan benda, ketebalan Printing, bentuk struktur dalam sebagai pengisi benda dan lain-lain. Disamping itu, diuji pula batasanbatasan yang dimiliki mesin terkait dengan ketebalan minimum yang boleh dipilih untuk suatu luas penampang benda. Selanjutnya pola-pola sambungan untuk 2 benda rakitan di telaah dan dilakukan proses pembuatannya. Sebagai komponen uji tunggal, benda hasil Printing juga diuji kekuatan mekanisnya, antara lain kekuatan Tarik dan kekuatan tekan untuk bentuk struktur dalam berupa honey-comb. Variasi yang dilakukan adalah dengan mengubah nilai densitas struktur dalam suatu penampang tertentu erta perubahan bentuk struktur berubah hierarchical.

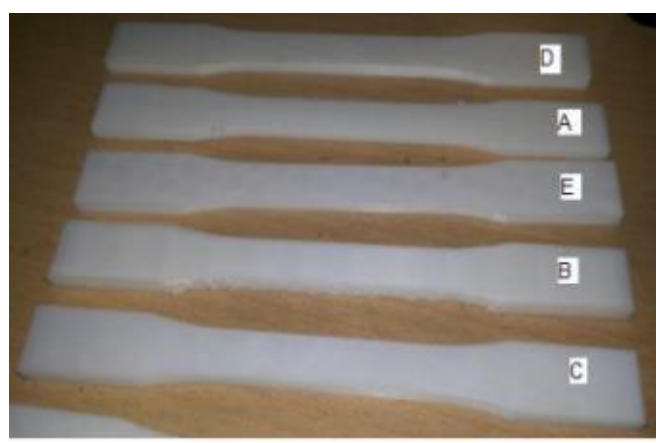

Gambar 1. Spesimen Uji Tarik Hasil 3D Printing

Dari pengujian ini dapat disimpulkan bahwa pada uji Tarik disimpulkan bahwa specimen D memiliki densitas $15 \%$ dengan orientasi Printing (c) merupakan specimen yang paling layak dijadikan rujukan untuk membuat produk prototype yang mungkin terkena beban Tarik. Sementara terkain dengan beban tekan, maka specimen B dimana densitas yang dimiliki adalah $10 \%$ dengan bentuk cellular honey-comb menjadi rujukan untuk membuat produk prototype yang mungkin terkena beban tekan. 

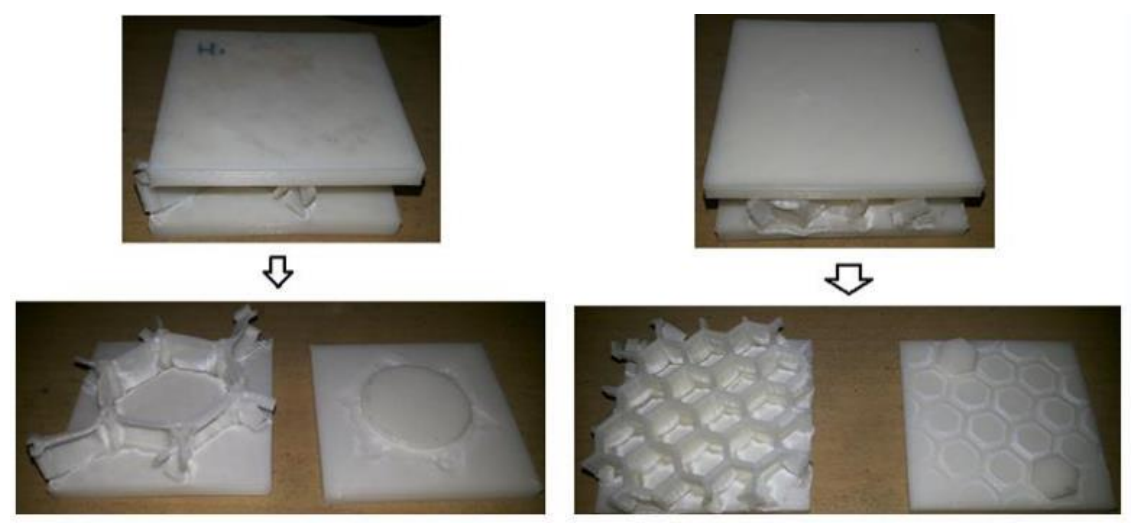

Gambar 2. Contoh Spesimen Uji Tekan Pada Struktur Honey_comb

Menurut Sulayman, Waluyo F, \& Sugito (2015) Fenomena mudahnya membuat suatu produk dengan menggunakan Rapid Prototyping ini adalah alasan mengapa teknologi ini semakin diminati dan digunakan secara luas oleh Industri Rekayasa dan Jasa untuk membantu kelancaran dalam membuat produk baru maupun usahanya. Suatu organisasi ataupun Perguruan Tinggi perlu memiliki pengetahuan yang baik bila ingin memanfaatkan keunggulan yang dimiliki oleh teknologi Rapid Prototyping, hal ini penting karena dalam rangka meningkatkan Daya Saing suatu Perguruan Tinggi dalam melek Teknologi. Salah satu jenis Rapid Prototyping yang mudah ditemui saat ini adalah 3D-Printer. 3D-Printer bekerja dengan cara lapis demi lapis dengan mengandalkan komponennya seperti heater nozzle.

Saat ini belum banyak Perguruan Tinggi yang fasih memanfaatkan keunggulan teknik 3DPrinter. Maka dari itu perlu dilakukan suatu Penelitian yang berkaitan dengan teknologi tersebut, karena selain untuk kepentingan Penelitian juga dapat digunakan untuk meningkatkan kapasitas Laboratorium, khususnya Laboratorium Computer Aided Design (CAD).

Untuk memanfaatkan teknologi ini perlu banyak mengenal tentang jenis-jenis Filamen yang digunakan dalam mencetak benda. Banyak jenis Filamen yang beredar saat ini, tetapi bahan yang saling sering digunakan adalah seperti Acrylonitrile Butadiene Styrene (ABS) dan Polylactic Acid (PLA). Permasalahnnya adalah belum dapat menentukn filamen mana yang terbaik untuk digunakan. Ada beberapa kriteria filamen yang harus diketahui dalam proses cetak dengan 3DPrinter, Baik dari segi tingkat titik leleh, kepresisian ukuran produk, kekuatan tekan, kekuatan Tarik, dll.

3D-Printer ini diteliti untuk mengetahui pengaruh suhu pada heater nozzle terhadap kekuatan bending pada hasil 3D printer filament ABS dan PLA, sehingga dapat diketahui filament mana yang paling kuat terhadap beban bending.

\section{METODOLOGI PENELITIAN}

Spesimen yang digunakan dalam penelitian ini menggunakan 2 macam Filamen, yaitu: PLA dan ABS. Dalam proses pembuatan nya menggunakan suhu nozzle $230^{\circ} \mathrm{C}, 237^{\circ} \mathrm{C}$ dan $244^{\circ} \mathrm{C}$. Selanjutnya proses pembuatan spesimen diawali dengan membuat gambar spesimen yang akan dibuat menggunakan software Catia. Ukuran spesimen yang digambar sesuai dengan standart ASTM D955. 


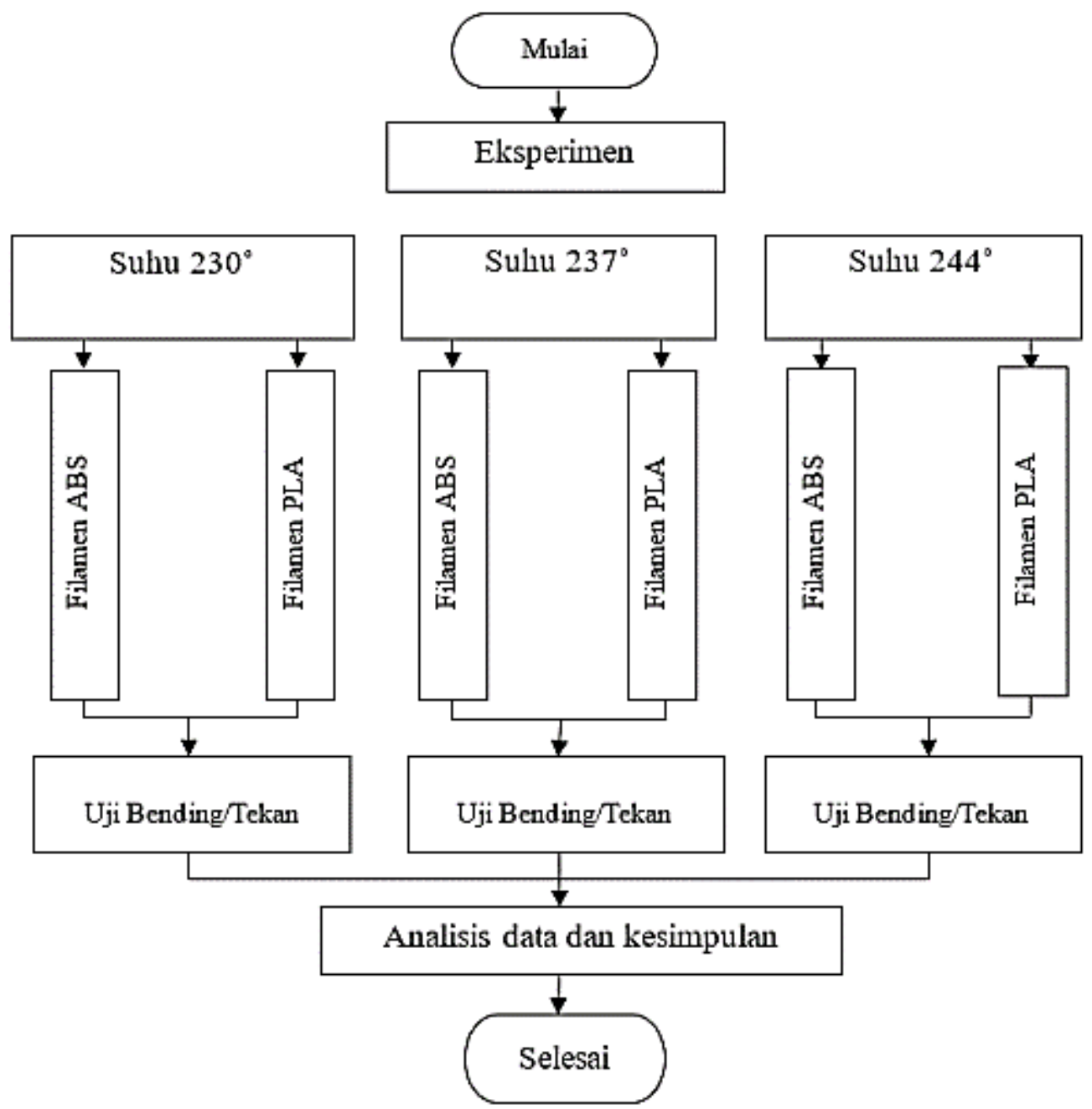

Gambar 3. Diagram Alir Penelitian

\section{HASIL DAN PEMBAHASAN}

\subsection{Studi Kekuatan Filamen dengan Uji Bending}

Spesimen yang terdiri dari 9 spesimen PLA dan 9 spesimen ABS dilakukan uji bending untuk mengetahui tingkat kekuatan spesimen terhadap suatu beban. Untuk pengujian bending yang dilakukan menggunakan parameter displacement sebesar $3 \mathrm{~mm}$. Pada setiap Filamen akan diberikan beban hingga mencapai displacement sebesar $3 \mathrm{~mm}$, kemudian dihasilkan gaya yang bekerja pada masing-masing Filamen. 
Tabel 1. Hasil Pengujian Bending pada Spesimen ABS dan PLA

\begin{tabular}{|c|c|c|c|c|c|}
\hline & \multicolumn{4}{|c|}{ FAKTOR B } & \multirow[b]{3}{*}{ Rata-rata } \\
\hline & \multicolumn{4}{|c|}{ Suhu Heater Nozzle } & \\
\hline & & $230^{\circ}$ & $237^{\circ}$ & $244^{\circ}$ & \\
\hline \multirow{8}{*}{ 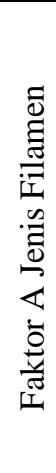 } & \multirow{3}{*}{ ABS } & 27.860 & 26.291 & 28.351 & \\
\hline & & 26.340 & 27.909 & 27.909 & \\
\hline & & 26.389 & 27.223 & 28.449 & \\
\hline & Rata-rata & 26.863 & 27.141 & 28.236 & 27.414 \\
\hline & \multirow{3}{*}{ PLA } & 22.367 & 24.035 & 26.781 & \\
\hline & & 21.533 & 23.544 & 28.155 & \\
\hline & & 23.249 & 23.544 & 29.234 & \\
\hline & Rata-rata & 22.380 & 23.708 & 28.057 & 24.716 \\
\hline
\end{tabular}

\subsection{Pembahasan Hasil Uji Bending Pada Filamen ABS}

Hasil pengujian bending dihasilkan beban yang bekerja pada Filamen ABS dengan variasi suhu $230^{\circ} \mathrm{C}, 237^{\circ} \mathrm{C}$, dan $244^{\circ} \mathrm{C}$. Beban pada pengujian bending direkam pada saat Filamen mencapai displacement sebesar $3 \mathrm{~mm}$.

Hasil dari pengukuran seperti yang ditunjukkan pada gambar 4 diketahui bahwa, Filamen ABS dengan suhu $230^{\circ} \mathrm{C}$ dapat menahan beban sebesar 26.863 N, Filamen ABS dengan suhu $237^{\circ} \mathrm{C}$ dapat menahan beban sebesar $27.141 \mathrm{~N}$, dan Filamen ABS dengan suhu $244^{\circ} \mathrm{C}$ dapat menahan beban sebesar $28.236 \mathrm{~N}$.

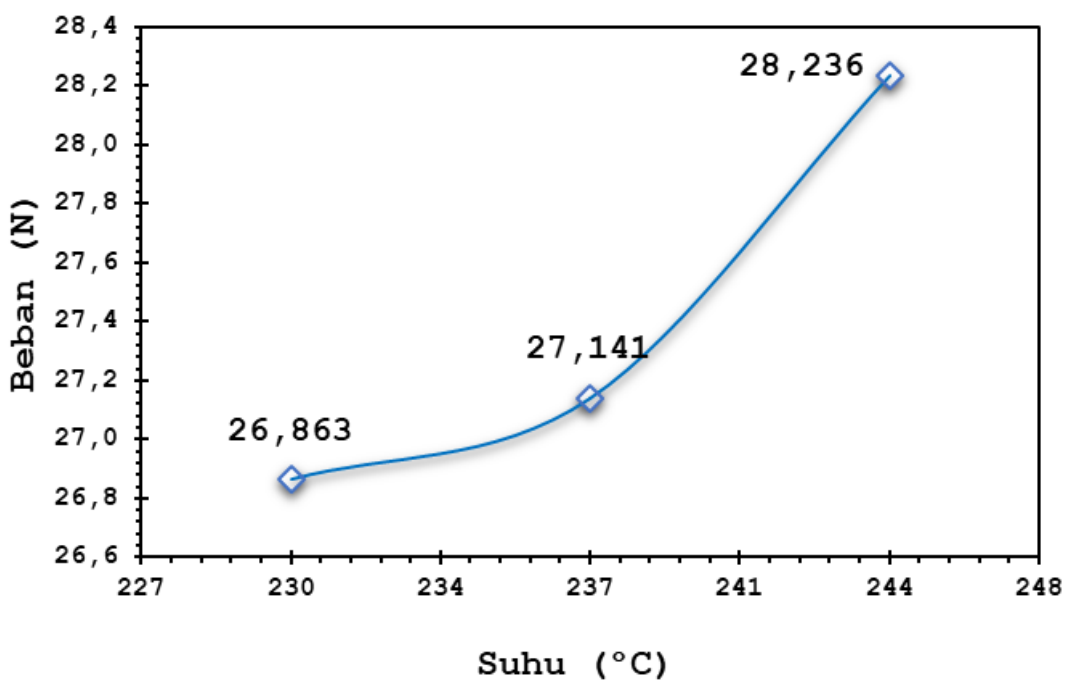

Gambar 4. Hasil Pengukuran Beban pada ABS

Berdasar grafik hasil pengukuran Filamen ABS diatas menunjukkan bahwa, hasil 3D Printing dengan suhu nozzle semakin tinggi maka beban yang dapat ditahan semakin besar. Hal ini berlaku 
sebaliknya, yaitu hasil 3D Printing dengan suhu nozzle semakin rendah maka beban yang dapat ditahan semakin kecil pula.

Hasil yang ditunjukkan pada gambar grafik serta fakta yang ditemukan maka dapat diambil kesimpulan bahwa semakin tinggi suhu pada saat proses 3D Printing Filamen jenis ABS maka hasilnya akan semakin kuat dan kelenturannya berkurang.

\subsection{Pembahasan Hasil Uji Bending Pada Filamen PLA}

Hasil pengujian bending dihasilkan beban yang bekerja pada Filamen PLA dengan variasi suhu $230^{\circ} \mathrm{C}, 237^{\circ} \mathrm{C}$, dan $244^{\circ} \mathrm{C}$. Beban pada pengujian bending direkam pada saat Filamen mencapai displacement sebesar $3 \mathrm{~mm}$.

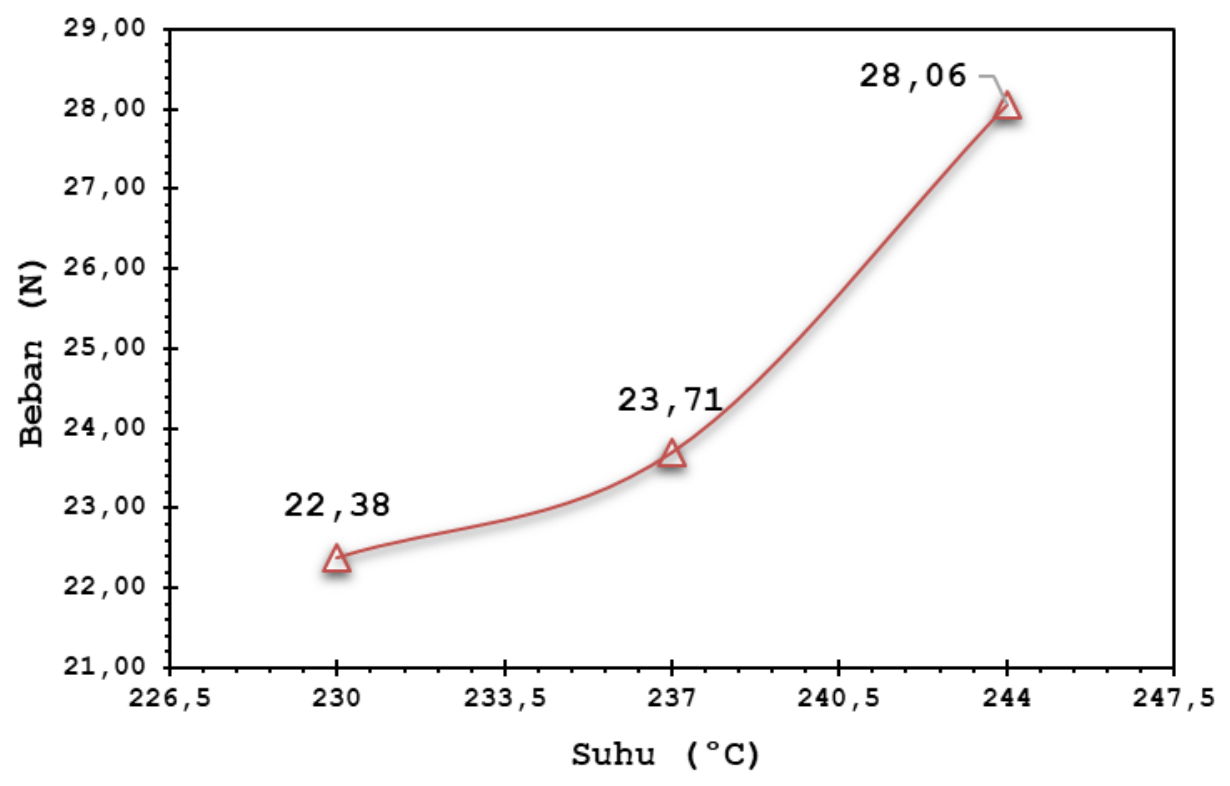

Gambar 5. Hasil Pengukuran Beban pada PLA

Hasil dari pengukuran seperti yang ditunjukkan pada gambar 5 diketahui bahwa, Filamen PLA dengan suhu $230^{\circ} \mathrm{C}$ dapat menahan beban sebesar $22.38 \mathrm{~N}$, Filamen PLA dengan suhu $237^{\circ} \mathrm{C}$ dapat menahan beban sebesar $23.71 \mathrm{~N}$, dan Filamen PLA dengan suhu $244^{\circ} \mathrm{C}$ dapat menahan beban sebesar $28.06 \mathrm{~N}$.

Berdasar hasil pengujian bending pada grafik hasil pengukuran Filamen PLA menunjukkan bahwa, hasil 3D Printing dengan suhu semakin tinggi maka beban yang dapat ditahan semakin besar. Hal ini berlaku sebaliknya, yaitu hasil 3D Printing dengan suhu semakin rendah maka beban yang dapat ditahan semakin kecil pula.

Hasil yang ditunjukkan pada gambar grafik serta fakta yang ditemukan maka dapat diambil kesimpulan bahwa semakin tinggi suhu nozzle pada saat proses 3D Printing Filamen jenis PLA maka hasilnya akan semakin kuat dan kelenturannya berkurang.

\subsection{Perbandingan Hasil Uji Bending Pada Filamen ABS dan PLA}




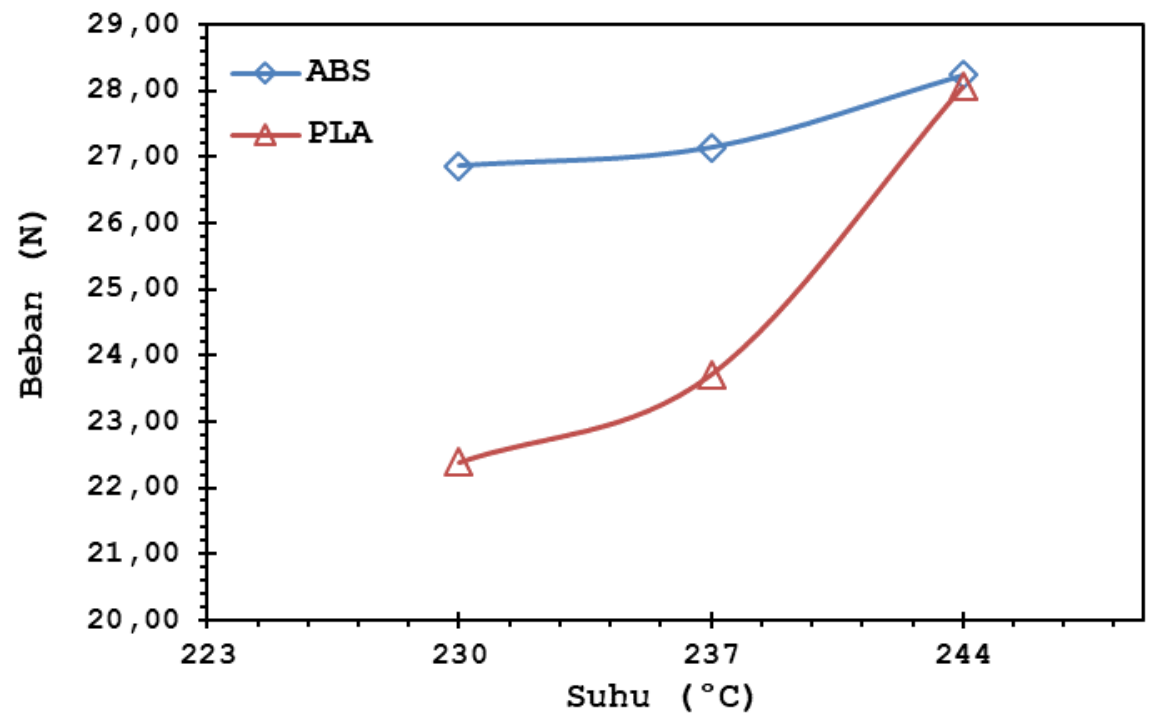

Gambar 6. Perbandingan Hasil Uji Bending Pada Filamen ABS dan PLA

Secara umum pada gambar 6 menunjukkan grafik perbandingan bahwa Filamen ABS lebih kuat menahan beban daripada Filamen jenis PLA, tetapi Filamen PLA lebih lentur dibandingkan dengan Filamen jenis ABS.

ABS lebih kuat daripada PLA karena dari hasil uji bending untuk mencapai displacement 3 mm, Filamen ABS mampu menahan beban yang lebih berat daripada Filamen PLA. PLA lebih lentur daripada ABS didasarkan pada hasil uji bending menunjukkan bahwa untuk mencapai displacement 3 mm, Filamen PLA memerlukan beban yang lebih ringan daripada Filamen ABS.

Pada penelitian ini ditemukan fakta bahwa terdapat satu titik pertemuan yang menghasilkan kesamaan sifat antara Filamen ABS dan PLA, yaitu hasil 3D Printing dengan suhu nozzle $244^{\circ} \mathrm{C}$. Filamen ABS menunjukkan angka 28.236 N sedangkan Filamen PLA menunjukkan angka 28.06 N. Fenomena ini menunjukkan bahwa sifat dari Filamen ABS dan PLA dihasilkan karakteristik yang relative sama apabila dilakukan Printing pada suhu $244^{\circ} \mathrm{C}$.

\section{KESIMPULAN}

Berdasarkan hasil pengujian bending pada Filamen ABS dan PLA dengan variasi suhu $230^{\circ} \mathrm{C}$, $237^{\circ} \mathrm{C}$, dan $244^{\circ} \mathrm{C}$, maka dapat diambil kesimpulan sebagai berikut:

1. Filamen $\mathrm{ABS}$ dengan suhu $230^{\circ} \mathrm{C}$ dapat menahan beban sebesar $26.863 \mathrm{~N}$, Filamen $\mathrm{ABS}$ dengan suhu $237^{\circ} \mathrm{C}$ dapat menahan beban sebesar 27.141 N, dan Filamen ABS dengan suhu $244^{\circ} \mathrm{C}$ dapat menahan beban sebesar $28.236 \mathrm{~N}$. sedangkan Filamen PLA dengan suhu $230^{\circ} \mathrm{C}$ dapat menahan beban sebesar 22.38 N, Filamen PLA dengan suhu $237^{\circ} \mathrm{C}$ dapat menahan beban sebesar $23.71 \mathrm{~N}$, dan Filamen PLA dengan suhu $244^{\circ} \mathrm{C}$ dapat menahan beban sebesar $28.06 \mathrm{~N}$.

2. Berdasar hasil pengukuran menggunakan Uji Bending menunjukkan bahwa, hasil 3D Printing dengan suhu nozzle semakin tinggi maka beban yang dapat ditahan semakin besar. Hal ini berlaku sebaliknya, yaitu hasil 3D Printing dengan suhu nozzle semakin rendah maka beban yang dapat ditahan semakin kecil pula.

3. Filamen ABS lebih kuat menahan beban daripada Filamen jenis PLA, tetapi Filamen PLA lebih lentur dibandingkan dengan Filamen jenis ABS. ABS lebih kuat daripada PLA karena dari hasil uji bending untuk mencapai displacement $3 \mathrm{~mm}$, Filamen ABS mampu menahan beban yang lebih berat daripada Filamen PLA. PLA lebih lentur daripada ABS didasarkan pada 
hasil uji bending menunjukkan bahwa untuk mencapai displacement $3 \mathrm{~mm}$, Filamen PLA memerlukan beban yang lebih ringan daripada Filamen ABS.

4. Terdapat satu titik pertemuan yang menghasilkan kesamaan sifat antara Filamen ABS dan PLA, yaitu hasil 3D Printing dengan suhu nozzle $244^{\circ} \mathrm{C}$. Filamen ABS menunjukkan angka 28.236 N sedangkan Filamen PLA menunjukkan angka 28.06 N. Fenomena ini menunjukkan bahwa sifat dari Filamen ABS dan PLA dihasilkan karakteristik yang relative sama apabila dilakukan Printing pada suhu $244^{\circ} \mathrm{C}$.

\section{DAFTAR PUSTAKA}

Amri, A. A., \& Sumbodo, W. (2018). Perangangan 3D Printer Tipe Core XY Berbasis Fused Deposition Modeling (FDM) Menggunakan Software Autodesk Inventor 2015 . Jurnal Dinamika Vokasional Teknik Mesin, 110-115.

Arthaya, B., \& Fransiscus, H. (2015). Eksplorasi Kemampuan dan Kapasitas Mesin 3D Printing dalam Pengembangan Modul Rakitan dan Komponen UJi. Bandung: LPPM UNPAR.

Attaran, M. (2017). The rise of 3-D Printing: The advantages of additive manufacturing over traditional manufacturing. bUSSINER hORIZON, 677-788.

Pristiansyah, \& Herianto. (2018). Pengaruh Parameter 3D Printing Terhadap Transparansi Produk yang Dihasilkan. Seminar Nasional Inovasi Teknologi. Kediri: UN PGRI.

Seprianto, D., Wilza, R., \& Iskandar. (2017). Optimasi Parameter Pada Proses Pembuatan Objek 3D Printing Dengan Teknologi FDM Terhadap Akurasi Geometri. Seminar Nasional Teknik Industri UGM. Yogyakarta.

Sulayman, D., Waluyo F, B., \& Sugito, B. (2015). Pengaruh Suhu dari Heater Nozzle Terhadap Produk Printer 3D. Surakarta. 